\title{
THE GENERA OF CHRYSOBALANACEAE IN THE SOUTHEASTERN UNITED STATES ${ }^{1}$
}

\author{
GHillean T. Prance
}

\section{CHRYSOBALANACEAE R. Brown in Tuckey, Narrat. Exped. Zaire Congo. 433. 1818, nom. cons.}

Small trees [to large ones], shrubs or subshrubs, with simple, entire, alternate, stipulate, pinnately veined leaves. Inflorescence of terminal and subterminal cymose panicles or terminal and axillary cymules [racemose, spicate, paniculate]. Flowers perfect [rarely polygamous], perigynous, actinomorphic [to markedly zygomorphic]. Sepals 5, regular [often unequal], distinct, imbricate in aestivation. Petals 5 [rarely apetalous], inserted on margin of disc, equal in size [unequal], imbricate in aestivation [rarely clawed]. Disc always present, forming a lining to floral tube. Stamens numerous, 12-26 [few to numerous, 2-300], inserted around margin of disc [or unilaterally], all fertile [or some reduced to long or short staminodia]; filaments elongated filiform, free or united below up to half their length in small groups [short to elongated, rarely ligulately connate], slightly exserted beyond calyx lobes [included to far exserted], glabrous or pubescent; anthers bilocular at anthesis, longitudinally dehiscent; pollen medium sized, with 3 furrows [rarely 4], oblate-spheroidal to subprolate, triangular in polar view, with little wall patterning, scabrous to verrucose. Gynoecium unicarpellate [basically of three, but usually only one developed], inserted at base of floral tube [from base to mouth of floral tube], sessile [rarely with a short gynophore]; style single, basally attached; stigma 3-lobed [or truncate]; ovary superior, 1-locular with 2 basally attached erect anatropous ovules [rarely 2-locular with one ovule in each locule]. Fruit a fleshy [or dry] drupe. Seed lacking endosperm, embryo large, with plano-convex [or amygdaloid or ruminate] cotyledons. Type genus: Chrysobalanus L.

An almost exclusively pantropical family of 17 genera and about 430 species; only Chrysobalanus and Licania extend into the southeastern United States. The family is divided into tribes Chrysobalaneae and Hirtelleae; both genera of our area belong to the former.

The family has usually been considered to be a subfamily or tribe of

${ }^{1}$ Prepared for a generic flora of the southeastern United States, a project of the Arnold Arboretum and the Gray Herbarium of Harvard University made possible through the support of the National Science Foundation (Grant GB-6459X, principal investigator Carroll E. Wood, Jr.). The treatment in this paper, which is the 55th published in the series, follows the format established in the first paper (Jour. Arnold Arb. 39: 296-346. 1958): The area covered includes North and South Carolina, Georgia, Florida, Tennessee, Alabama, Mississippi, Arkansas, and Louisiana. The descriptions are based primarily on the plants of this area, with additional information in brackets. References that have not been seen and verified are marked by an asterisk.

The plate was drawn by Miss Alma Hochhauser. I wish to thank Dr. Wood for his advice and helpful suggestions during the preparation of this manuscript. 
the Rosaceae, but it is markedly distinct from that family, differing in the gynobasic style, the erect ovule, the tendency toward zygomorphic flowers, the rubiaceous stomata, the presence of silica, the pollen morphology, and in numerous anatomical features, especially the secondary xylem. The Chrysobalanaceae form a well-marked and natural family. Various phylogenists have suggested diverse relationships for the family but it seems to belong to the Rosales between the Rosaceae and Leguminosae. Small and a few other authors have placed the Chrysobalanaceae in the family Amygdalaceae, which consists of the Chrysobalanaceae and Rosaceae subfam. Prunoideae. This is, however, an unnatural grouping, and the Prunoideae clearly belong with the rest of the Rosaceae, rather than with the Chrysobalanaceae. The anatomy of these two groups is very different, and the morphological features given above also separate them.

The generic limits within the family have recently been redefined on a worldwide basis (Prance, 1969, \& in press), and as now defined they are relatively distinct. The result of this work shows that two genera are represented in our area. One species previously considered a member of Chrysobalanus or as the separate genus Geobalanus has been transferred to Licania, a widespread, predominantly neotropical genus.

\section{REFERENCES:}

Balllon, H. Monographie des Rosacées. Hist. Pl. 1: 345-483. 1869. [Série des Icaquiers, 425-439; Chrysobalaneae, 480-483.]

Bentham, G. Contributions towards a flora of South America. - Enumeration of plants collected by Mr. Schomburgk in British Guiana. Hook. Jour. Bot. 2: 210-223. 1840. [Chrysobalanaceae, 210-222.]

\& J. D. Hooker. Rosaceae. Gen. Pl. 1: 600-629. 1865. [Treatment by Hooker; Chrysobalaneae, 606-609.]

Bonne, G. Sur la constitution du gynécée chez les Chrysobalanées. Compt. Rend. Acad. Sci. Paris 182: 1404-1406. 1926.

- Recherches sur le pédicelle et la fleur des Rosacées. 380 pp., 10 pls. Paris. 1928.

Candolle, A. P. De. Rosaceae. Prodr. 2: 525-639. 1825. [Tribe Chrysobalaneae, 525-529.]

Cronquist, A. Evolution and classification of flowering plants. xii +396 pp. Boston. 1968. [Rosales, 229-236; Chrysobalanaceae, 235.]

Duke, J. A. On tropical tree seedlings. I. Seeds, seedlings, systems, and systematics. Ann. Missouri Bot. Gard. 56: 125-161. 1969. [Chrysobalanaceae, 148.]

Eichler, A. W. Rosaceae. Blüthendiagramme 2: 495-514. 1878. [Chrysobalaneae, 511-514.]

Focke, W. O. Rosaceae. Nat. Pflanzenfam. III. 3: 1-48. 1888; 49-64. 1891. [Chrysobalanoideae, 55-60.]

Fritsch, C. Ueber die Gattungen der Chrysobalanaceen. Verh. Zool.-Bot. Ges. Wien 38: 93-95. 1888.

. Beiträge zur Kentniss der Chrysobalanaceen. I. Conspectus generis Licaniae. Ann. Naturh. Hofmus. Wien 4: 33-60. 1889.

Grisebach, A. H. R. Flora of the British West Indian Islands. xvi +789 pp. London. 1860. [Chrysobalaneae, 229-231.] 
Gundersen, A. The families of dicotyledons. xviii $+237 \mathrm{pp}$. Waltham, Mass. 1950. [Chrysobalanaceae, 109.]

Hauman, L. Contribution à l'étude des Chrysobalanoideae africaines. Bull. Jard. Bot. Bruxelles 21: 167-198. 1951.

Hutchinson, J. Rosaceae. Gen. Fl. Pl. 1: 174-216. 1964. [Chrysobalaneae, 190-193.]

Küster, E. Die anatomischen Charaktere der Chrysobalaneen, insbesondere ihre Kieselablagerungen. Bot. Centralbl. 69: 46-54, 97-106, 129-139, 161-169, 193-202, 225-235. pl. 1. 1897.

Lindley, J. A natural system of botany. ed. 2. xxvi + 526 pp. London. 1836. [Chrysobalanaceae, 158, 159.]

Melchior, H. Chrysobalanaceae. Engler's Syllab. Pflanzenfam. ed. 12. 2: 219, 220. 1964.

Morvillez, F. La trace foliare des Chrysobalanées. Compt. Rend. Acad. Sci. Paris 166: 859-861. 1918.

Prance, G. T. The taxonomy and ecology of the Chrysobalanaceae of the Amazon Basin. In: H. Lint, ed. Atas do Simpósio sôbre a Biota Amazônica 4: 209-228. 1967.

- A synopsis of Chrysobalanaceae. (In press.) Oxford.

, D. J. Rogers, \& F. White. A taximetric study of an angiosperm family:

generic delimitation in the Chrysobalanaceae. New Phytol. 68: 1203-1234. 1969.

Small, J. K. Manual of the southeastern flora. xxii +1554 pp. New York. 1933. (Reprinted by Univ. N. Carolina Press, Chapel Hill.) [Amygdalaceae, $645,646$.

Wettstein, R. Handbuch der systematischen Botanik. $x+1152$ pp. Leipzig \& Wien. 1935. [Chrysobalanaceae, 771, 772.]

\section{Key to the Genera of Chrysobalanaceae in the Southeastern United States}

Plants shrubs or small trees; staminal filaments pubescent, joined in small groups up to half their length; endocarp longitudinally ribbed (costate); inflorescences axillary.

1. Chrysobalanus.

Plants suffruticose, low, colonial, spreading by woody underground stems; staminal filaments glabrous, connate at base only; endocarp smooth, not ribbed; inflorescences terminal and subterminal.

2. Licania.

1. Chrysobalanus Linnaeus, Sp. Pl. 1: 514. 1753; Gen. Pl. ed. 5. 299. 1754.

Small to large shrubs, or rarely small trees, with coriaceous pinnately veined leaves, often with two glands at base of blade. Inflorescence few flowered, terminal or axillary, either a short raceme of cymules or cymose throughout, or, when consisting of about 6 flowers, a false raceme. Sepals acute, pubescent. Petals equaling sepals, glabrous, white. Stamens 12-26, exserted beyond sepals, some often shorter than others, inserted in a complete circle around disc [slightly unilateral]; filaments united in small groups for up to half their length [free almost to base], densely hairy. Style inserted at base of ovary, pubescent for most of its length; ovary pilose, inserted at base of floral tube, 1-locular, with two erect ovules. 


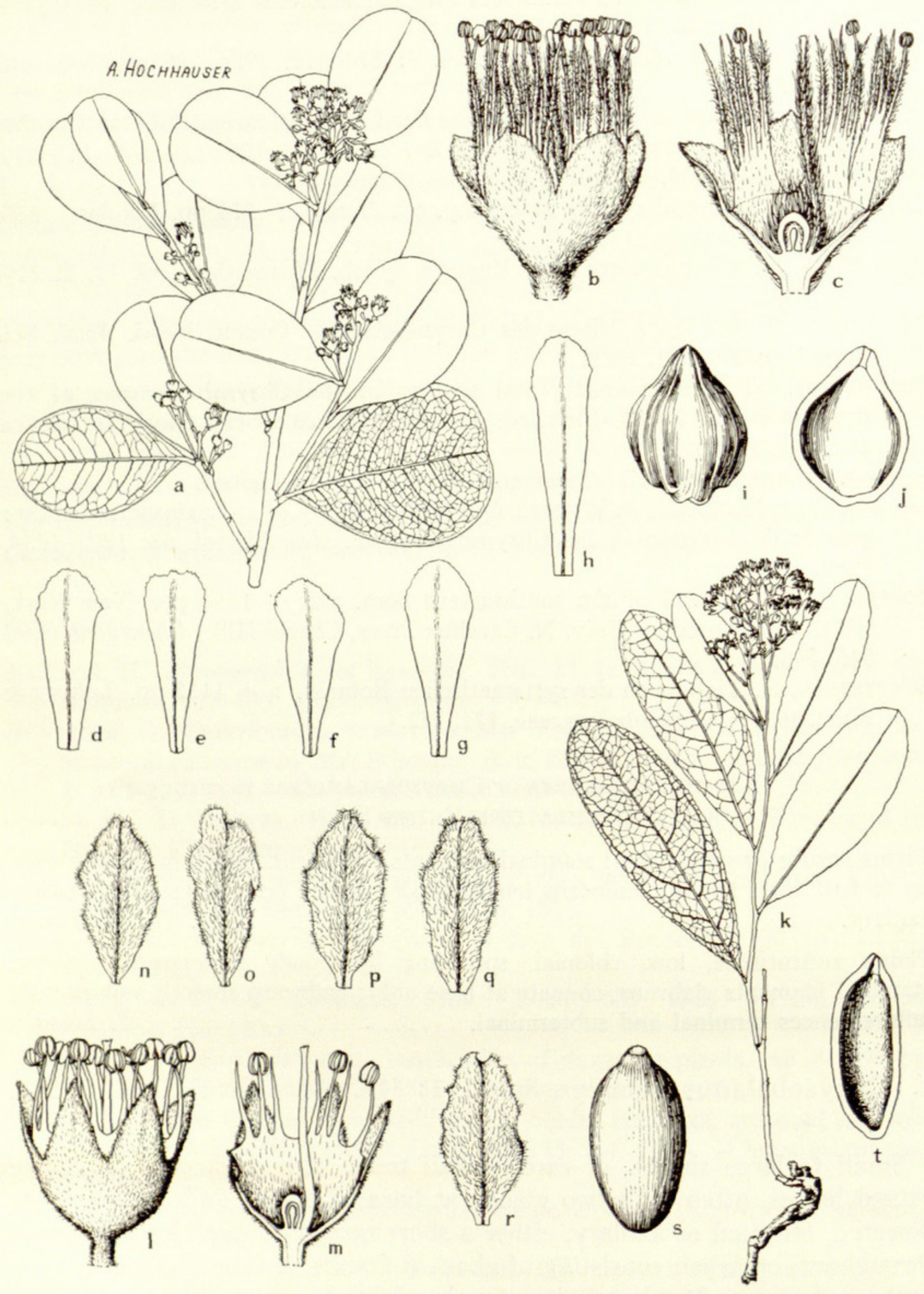

Figure 1. Chrysobalanaceae. a-j, Chrysobalanus. C. Icaco: a, habit, $X$ $1 / 2 ; b$, flower, $\times 4$; c, flower in vertical section, $\times 4 ; d-h$, petals, $\times 4 ; i$, fruit, $\times 1 ; \mathrm{j}$, fruit in vertical section, $\times 1$. $\mathrm{k}-\mathrm{t}$, Licania. L. Michauxii: $\mathrm{k}$, habit, $\times$ $1 / 2 ; 1$, flower, $\times 4 ; \mathrm{m}$, flower in vertical section, $\times 4 ; n-r$, petals, $\times 4$; s, fruit, $\times 1 ; t$, fruit in vertical section, $\times 1$. 
Fruit a small ellipsoid fleshy drupe, smooth, longitudinally ribbed; endocarp thin, hard, with 4-8 prominent longitudinal ridges corresponding to lines of fracture that allow the seedling to escape, glabrous within, filled by the large plano-convex cotyledons. Germination hypogeal. TyPe SPEcIES: Chrysobalanus Icaco L. (Name derived from Greek chrysos, golden, and balanos, acorn or fruit.)

A primarily tropical genus of four species, two confined to Africa and one to the West Indies. The fourth, Chrysobalanus Icaco, cocoa plum, is a widespread coastal species from subtropical Florida through the Caribbean and Central America to eastern South America and West Africa. In the southern part of peninsular Florida $C$. Icaco is a common shrub or tree of beaches, sand dunes, coastal hammocks, hammock islands in the Everglades, and cypress-heads.

The extreme variation in leaf shape and size and fruit size in Chrysobalanus Icaco has led to the description of numerous taxa throughout its range (e.g., in our area, $C$. interior Small). There is, however, little correlation of the variable characters, and there seems to be no basis for recognition of more than one species. In at least Trinidad, Suriname, and Brazil, the different forms are frequently found growing side by side without any ecological separation (obs. Prance). The leaves vary from extremely small to large and from orbicular to elliptic, and both shape and size are quite variable on the same plant. The very variable fruit is from 0.8 to $4.5 \mathrm{~cm}$. long. The larger fruits are more conspicuously ribbed than the smaller ones, and they tend to have a thicker, more fleshy mesocarp. In addition, the mature fruit may be deep red or purple to black or yellow. (To judge from the name of the genus, the material described by Linnaeus must have been of the yellow-skinned form.) The fruit is edible, but only the larger, more fleshy fruits borne by some plants make good eating, the differences in fruit type being comparable to those between good and bad varieties of plum (Prunus domestica L.). Where C. Icaco is used commercially there is obviously some selection of plants. For the present, it seems best to maintain only a single polymorphic species, for it is impossible to subdivide this species on the basis of herbarium material and ecology alone. An experimental study of plants of the different morphological types grown in controlled environments should yield much additional information. Attempts to examine the chromosomes of C. Icaco have thus far proved unsuccessful.

The fruits of Chrysobalanus Icaco are commonly used for preserves in Venezuela and Colombia, but only occasionally in our area. Plants of this species are sometimes grown as ornamentals.

Chrysobalanus is most closely related to Licania, a predominantly neotropical genus. The differences between the two are small, but a study of these genera on a worldwide basis shows that they are best kept apart. Chrysobalanus differs from Licania in the ridged endocarp of the fruit, in the hairy filaments that are joined together in small groups, and in the inflorescence. 


\section{REFERENCES:}

Under family references see Bentham \& Hooker (p. 606), Bonne (1928, pp. 163, 244-346, 356), Focke (p. 57), Grisebach (p. 229), Hutchinson, Küster (pp. 135-137), Prance (1967, p. 216; 1970, in press), and Small (p. 645).

Hauman, L. Contribution à l'étude des Chrysobalanoideae africaines. Bull. Jard. Bot. Bruxelles 21: 167-198. 1951. [C. Icaco \& C. orbicularis Schumach., 172, 173.]

Howard, R. A. Notes on Rosaceae in the Lesser Antilles. Jour. Arnold Arb. 45: 279-283. 1964. [C. cuspidatus Griseb. (Licania oligantha A. C. Sm.), 279-281.]

Hutchinson, J., \& J. M. Dalziel. Chrysobalamus. Fl. W. Trop. Afr. ed. 2. 1: 426, 427. 1958. [3 spp.; ed. 2 revised by R. W. J. KEAY.]

Small, J. K. Notes on Chrysobalamus Icaco L. Torreya 10: 249. 1910. [Notes yellow, purple, or red fruits, the yellow largest, red smallest.]

TAvares, S. Contribuição para o estudo botanico de "guajeru" (Chrysobalanus Icaco L.). (English summary.) Inst. Pesquisas Pernambuco Agron. Publ. II. 1.12 pp. $1957 . *$

\section{Licania Aublet, Hist. Pl. Guiane Franç. 1: 119. pl. 45. 1775.}

Subshrubs [shrubs to large trees] with coriaceous [membranaceous to chartaceous] pinnately veined leaves. Inflorescences rather lax branched terminal and subterminal cymose panicles [or a sparsely branched panicle of racemes, a panicle, or a spike]. Sepals acute [or rounded], pubescent [to glabrous]. Petals equaling sepals [larger or smaller than sepals, or absent], pubescent [glabrous]. Stamens 14-17 [3-40], exserted slightly beyond sepals [included to far exserted], inserted in a complete circle around disc [unilateral]; filaments united at base only [free to base], glabrous [rarely hairy, very short and included]. Style inserted at base of ovary, glabrous [to densely hairy]; ovary inserted at base of floral tube, usually 1-carpellate but sometimes 2 or 3 carpels developing, glabrous or sparsely hairy [to densely hairy], unilocular, with two erect ovules. Fruit a small ellipsoid drupe [to large and of varying shape], smooth, glabrous [sometimes verrucose, pulverulent or densely pubescent]; endocarp hard, thin [to thick] terete, not ridged, sparsely hairy [to densely hairy within], filled by the large cotyledons. Germination hypogeal. (Including $\mathrm{Mo}$ quilea Aubl., 1775; Hedycrea Schreb., 1789; Geobalanus Small, 1913; and others.) Type species: Licania incana Aublet. (Name a misspelled anagram derived from the local name in French Guiana, caligni.)

Primarily a neotropical genus of 151 species, in three subgenera and eight sections, with one species widespread in Malesia and one confined to our area.

Licania Michauxii Prance, ${ }^{2}$ gopher-apple or ground-oak, is a common

\footnotetext{
${ }^{2}$ Licania Michauxii Prance, nom. nov. Chrysobalanus oblongifolius Michx. Fl. Bor.Am. 1: 283. 1811, non Licania oblongifolia Standl., 1917; C. retusus Raf. New Fl. N. Am. 3: 26. 1838, non L. retusa Pilger, 1914; C. incanus Raf. loc. cit., non L. incana
} 
suffruticose shrub with spreading underground stems. It is abundant in pinelands and oak scrubland and on sand hills and sand-dunes in Florida and extends westward to Louisiana and northward to South Carolina. The full reasons for treating this species as a Licania instead of a Chrysobalanus will be given elsewhere (Prance, in press). The two genera are very closely related but are distinct when L. Michauxii is transferred from Chrysobalanus to Licania. It falls well within the limits of Licania, and there are no grounds whatever for regarding it as a separate genus. It is a member of subg. Moquilea (Aubl.) Prance (Atas Simp. Biota Amazôn. 4: 224. 1967 ), sect. Moquilea (Aubl.) Prance, ${ }^{3}$ and it is most closely related to L. retifolia Blake, of Mexico.

This species has previously been included in both Chrysobalanus L. and Geobalanus Small. Its synonyms include $C$. oblongifolius Michx., $C$. retusus Raf., C. incanus Raf., G. oblongifolius (Michx.) Small, G. pallidus Small, and $C$. pallidus (Small) L. B. Sm. Since the specific epithets of all these combinations are already occupied in Licania (i.e., L. incana Aubl., L. pallida Spruce ex Sagot, L. oblongifolia Standl., and $L$. retusa Pilger) a new epithet was required. Chrysobalanus prunifolius Raf. has commonly been referred to this species, but type material has not been found, and the small leaves, few-flowered racemes, and podlike fruit described for $C$. prunifolius are quite unlike those of $L$. Michauxii.

The differences given by Small for his Geobalanus pallidus (leaves densely white-tomentose beneath, ovary pubescent, drupes 3-4 cm. long vs. leaves and ovary glabrous, fruit $2-2.5 \mathrm{~cm}$. long in $G$. oblongifolius) do not hold. There is a gradation in the pubescence of both the ovary and the leaf undersurface, and in many cases the pubescence of the leaf is caducous and the older leaves are glabrous. Chrysobalanus incanus Raf., based on the variant noted by Michaux under his $C$. oblongifolius, represents the same pubescent form, which, although conspicuous in its extreme development, does not seem to be worthy of taxonomic rank.

Licania Michauxii has often been said to have a stellate pubescence, but it does not. This erroneous report, attributable to Küster, has led to the mention of stellate pubescence in connection with the family in several other publications. The mistake is based on a mixed collection of

Aubl., 1775; Geobalanus pallidus Small, Fl. Miami 81. 1913, non L. pallida Spruce ex Sagot, 1883, nec L. pallida Britton, 1890.

${ }^{3}$ Licania Aubl. sect. Moquilea (Aubl.) Prance, comb. nov. Moquilea Aubl. Hist. Pl. Guiane Franç. 1: 521. pl. 208. 1775.

This sectional combination, cited without an author, was used under Licania subg. Moquilea (Aubl.) Prance in 1967 (Atas Simp. Biota Amazôn. 4: 225), since this was the correct procedure under Art. 22, International Code of Botanical Nomenclature, 1966. However, changes adopted at the 11th International Botanical Congress, Seattle, 1969 , restrict this tautonymic principle to the subgenus and section that include the type of the genus, but recommend that when a new epithet is needed in other subgenera and sections the repetitive principle be retained when possible. In conformity with these changes the combination Licania sect. Moquilea is made here formally and is cited with authors. 
herbarium material. The widely distributed A. H. Curtiss 727 includes, in addition to L. Michauxii, sterile branches of Quercus pumila Walt., a plant that has stellate hairs on the lower leaf surface. Quercus pumila may have the same suffruticose habit as L. Michauxii, and sterile specimens could easily be mistaken for it, except for their stellate pubescence.

Licania is most closely related to Chrysobalanus $(q . v$.). It is also close to the African Afrolicania Mildbr. and the Malesian Parastemon A. DC. Together the four comprise the tribe Chrysobalaneae, which is distinguished by the regular flowers with a basally inserted gynoecium.

\section{REFERENCES :}

Under family references see Bonne (1928, pp. 164, 347, 348), Fritsch, Hutchinson (p. 191), Küster (pp. 137, 194-201), Prance (1967, pp. 224227; 1970, in press), and Small (p. 645, 646, as Geobalamus).

Adams, D. W. Gopher-root. Gard. Month. 28: 244. 1886. [Humorous nonscientific letter to editor concerning an underground tree identified in editor's comment following as Chrysobalamus oblongifolius. Adams notes spread of individual plant as 80-100 ft. and underground stems to 2.5 inches in diameter.]

Ahles, H. E., C. R. Bell, \& A. E. Radford. Species new to the flora of North or South Carolina. Rhodora 60:10-32. 1958. [L. Michauxii, as C. oblongifolius, in Jasper Co., S. C.; see also Manual of the vascular flora of the Carolinas, 569.]

Hooker, J. D. Rosaceae. In: C. F. P. von Martius, Fl. Brasil. 14(2): 1-76. pls. 1-22. 1867. [Licania, 8-19, pls. 1-4; Moquilea, 19-26, pls. 5-8.]

\section{B. A. Krukoff Curator of Amazonian Botany} The New York Botanical Garden

BRONX, NEW YoRk 10458 


\section{$2 \mathrm{BHL}$ Biodiversity Heritage Library}

Prance, Ghillean T. 1970. "The genera of Chrysobalanaceae in the southeastern United States." Journal of the Arnold Arboretum 51(4), 521-528. https://doi.org/10.5962/bhl.part.7048.

View This Item Online: https://www.biodiversitylibrary.org/item/41431

DOI: https://doi.org/10.5962/bhl.part.7048

Permalink: https://www.biodiversitylibrary.org/partpdf/7048

\section{Holding Institution}

Missouri Botanical Garden, Peter H. Raven Library

\section{Sponsored by}

Missouri Botanical Garden

\section{Copyright \& Reuse}

Copyright Status: In copyright. Digitized with the permission of the rights holder.

Rights Holder: Arnold Arboretum of Harvard University

License: http://creativecommons.org/licenses/by-nc-sa/3.0/

Rights: https://biodiversitylibrary.org/permissions

This document was created from content at the Biodiversity Heritage Library, the world's largest open access digital library for biodiversity literature and archives. Visit BHL at https://www.biodiversitylibrary.org. 